\title{
XDH wt Allele
}

National Cancer Institute

\section{Source}

National Cancer Institute. XDH wt Allele. NCI Thesaurus. Code C50947.

Human XDH wild-type allele is located in the vicinity of 2 p23.1 and is approximately $79 \mathrm{~kb}$ in length. This allele, which encodes xanthine dehydrogenase/oxidase protein, is involved in the stepwise oxidation of hypoxanthine to produce purine and ultimately uric acid.

Certain allelic variants of the XDH gene, which encode protein products with low enzymatic activity, cause xanthinuria. 